\title{
Alpha Thalassaemia: Experience of Referral Cases in Kolkata, India
}

\author{
Tapash Rudra, Sila Chakrabarti and Bani Sengupta \\ Thalassaemia Counselling Unit, Vivekananda Institute of Medical Sciences, 99 Sarat Bose \\ Road, Kolkata 700 026, West Bengal, India
}

KEYWORDS Haemoglobinopathies; Thalassaemia; anaemia, mutation

\begin{abstract}
Haemoglobinopathies and different forms of thalassaemias including alpha thalassaemia has been found to be as high as $10 \%$ in Eastern India. The alpha globin disorders are less commonly reported because the diagnosis of alpha thalassaemia is usually missed unless in the severe homozygous form or as $\mathrm{Hb}$ Barts. But presence of alpha gene has been found in cases of unexplained anaemias and also in several suspected cases having $\mid \alpha$ mutations and other common haemoglobinopathies. Two of the common $\mid \alpha$ mutations $(-|\alpha 3.7,-| \alpha 4.2)$ have been detected either in heterozygous or homozygous states in significant frequencies, so patients coming for Hb Electrophoresis and carrier detection should be also checked the alpha status through specific DNA studies.
\end{abstract}

\section{INTRODUCTION}

Thalassaemia describes a group of inherited disorders characterized by reduced or absent amounts of hemoglobin, the oxygen-carrying protein inside the red blood cells. There are two basic groups of Thalassaemia disorders: alpha Thalassaemia and beta Thalassaemia. These conditions cause varying degrees of anaemia, which can range from insignificant to life threatening.

All types of Thalassaemias are considered quantitative diseases of hemoglobin, because the quantity of hemoglobin produced is reduced or absent. Usual adult hemoglobin is made up of three components: alpha globin, beta globin, and heme. Thalassaemias are classified according to the globin that is affected, hence the names alpha and beta Thalassaemia. Although both classes of Thalassaemia affect the same protein, the alpha and beta Thalassaemias are distinct diseases that affect the body in different ways.

Most individuals have four normal copies of the alpha globin gene, two copies on each chromosome 16. These genes make the alpha globin component of normal adult hemoglobin, which is called hemoglobin A.

Alpha globin is also a component of fetal hemoglobin and the other major adult hemoglobin called hemoglobin A2. Mutations of the alpha

Address for correspondence: Tapash Rudra

Thalassaemia Counselling Unit, Vivekananda Institute of Medical Sciences, 99 Sarat Bose Road, Kolkata

700 026, west Bengal, India

E-mail: tapashrudra@yahoo.co.in globin genes are usually deletions of the gene, resulting in absent production of alpha globin. Since there are four genes (instead of the usual two) to consider when looking at alpha globin gene inheritance, there are several alpha globin types that are possible.

Absence of one alpha globin gene leads to a condition known as silent alpha Thalassaemia trait. This condition causes no health problems and can be detected only by special genetic testing. Alpha Thalassaemia trait occurs when two alpha globin genes are missing. This can occur in two ways. The genes may be deleted from the same chromosome, causing the 'cis' type of alpha Thalassaemia trait. Alternately, they may be deleted from different chromosomes, causing the 'trans' type of alpha Thalassaemia trait. In both instances, there are no associated health problems, although the trait status may be detected by more routine blood screening.

Hemoglobin $\mathrm{H}$ disease results from the deletion of three alpha globin genes, so that there is only one functioning gene. Typically, this can occur when one parent carries the silent alpha Thalassaemia trait, and the other parent carries the 'cis' type of the alpha Thalassaemia trait. In this situation, there is a $25 \%$ chance for hemoglobin $\mathrm{H}$ disease in each of such a couple's children.

Hemoglobin $\mathrm{H}$ disease-like symptoms can also be a part of a unique condition called alpha Thalassaemia mental retardation syndrome (ALMRS). Alpha Thalassaemia mental retardation syndrome can be caused by a deletion of a significant amount of chromosome 16, affecting 
the alpha globin genes. This is usually not inherited, but rather occurs sporadically in the affected individual. Affected individuals have mild hemoglobin $\mathrm{H}$ disease, mild-to-moderate mental retardation, and characteristic facial features. This syndrome can also occur as a sexlinked form in which a mutation is inherited in a particular gene on the X-chromosome. This gene influences alpha globin production, as well as various other developmental processes.

In homozygous $\{\alpha$-Thalassaemia, deletion of both copies of each of the two $\alpha$-globin genes on chromosome 16 occurs, thus no $\alpha$-globin is produced $\left({ }_{1}^{1} \alpha^{0}\right)$. The tetramers that are made, $\mathrm{Hb}$ Bart's $\left({ }_{1}^{\prime} \alpha_{4}\right)$ and $\mathrm{Hb} \mathrm{H}\left({ }_{1}^{\prime} \alpha_{4}\right)$, behave instead like myoglobin in that they do not readily give up oxygen at physiologic tensions leading to severe hypoxia. Affected infants have very high levels of Hb Bart's (which is unstable). Typically these newborns die in utero in the third trimester or in the early postnatal period. This condition has been called hydrops fetalis, and Hb Bart's hydrops or Hb Bart's disease.

Incidence of alpha thalassaemia is distributed throughout the world having high frequency in Asia, Africa, Mediterranean Region and Southeast Asia especially in India. Haemoglobinopathies and different forms of thalassaemias including alpha thalassaemia has been found to be as high as 10\% in Eastern India. In India there are so many alpha mutations are present of which (-SEA) deletion, (-KOL) deletion, -3.7 Kb deletion and $-4.2 \mathrm{~Kb}$ deletion are common. However, in our study we have examined $-3.7 \mathrm{~Kb}$ and $-4.2 \mathrm{~Kb}$ deletions in the population.

\section{MATERIAL AND METHODS}

Blood samples were collected in EDTA vials and following tests were carried out:

Haematocrit estimated by an automated cell counter, Sysmex K-4500 and b lood slide test for red cell morphology and other abnormalities with special stains, especially important for $\alpha$ Thalassaemia. Brilliant cresyl blue (BCB) used for Heinz body inclusions in red blood cells for $\mathrm{HbH}$ disease.

Naked eye single tube osmotic fragility test (NESTROFT) (Kattamis et al. 1981, Mahadik et al. 1986, Mehta et al. 1988) was carried out.

Agarose Gel Electrophoresis at $\mathrm{pH} 8.6$ for detection of Hb variants: (Adhikari et al. 1987).
The separation of different haemoglobins depends mainly on the charge of $\mathrm{Hb}$ molecules at alkaline $\mathrm{pH}$. Since this technique allows good separation to be obtained quickly between haemoglobin variants like $\mathrm{Hb} \mathrm{A} / \mathrm{F}$ etc., it is very useful as part of primary screening of common haemoglobin variants.

Quantitative Estimation of Fetal $\mathrm{Hb}$ by Alkaline Denaturation Test by modified Betke method (Betke et al,1959; Dacie and Lewis, 1990) was used for estimation of $\mathrm{Hb} \mathrm{F} \%$. To measure the $\mathrm{Hb} \mathrm{F} \%$ in a mixture of $\mathrm{Hb}, \mathrm{NaOH}$ is added to the haemolysate and after a set time denaturation was stopped by adding saturated ammonium sulphate to lower the $\mathrm{pH}$ and precipitate the denatured $\mathrm{Hb}$. After filtration, the quantity of undenatured (unprecipitated) $\mathrm{Hb}$ is measured. The proportion of alkali resistant $\mathrm{Hb}(\mathrm{Hb} \mathrm{F})$ is then calculated as a percentage of the total amount of $\mathrm{Hb}$ present.

Quantitative Estimation of $\mathrm{Hb} \mathrm{A}_{2}$ By Gel Elution Technique:

Slow moving $\mathrm{Hb}$ variants $\left(\mathrm{Hb} \mathrm{A}_{2}\right)$ is quantitiated in haemolysate samples. Estimation by $\mathrm{Gel}$ Elution from Agarose Gel (Adhikari et al. 1987).

In the cases which do not respond to iron therapy for six months DNA test is carried out with repeat $A_{2}$.

Serum iron and Total iron binding capacity (TIBC) measured following standard methods. (Worwood M1994)

PCR-ARMS Technique For Detection of $\beta$ Thalassaemia and other Haemoglobinopathy mutation at $\beta$-Globin Gene :

These can be characterized by ARMS technique. The Amplification Refractory Mutation System (ARMS) is a simple, rapid and nonisotropic method for the detection of mutations involving single base change or deletion (Newton et al, 1989). For $\mid \alpha$ Thalassaemia detection (common deletion found in Eastern India population), Single Tube Multiplex PCR Method is used to detect $\alpha^{+}$Thalassaemia alleles (Shaji et al. 2000, Baysal and Huisman 1994).

Sequences of primers used for the detection of the $-\alpha^{3.7}-\mathrm{Kb}$ and $-\alpha^{4.2}-\mathrm{Kb}$ deletions. The following common mutant primers used:

\begin{tabular}{lll}
\hline Primer & \multicolumn{2}{c}{ Sequences } \\
\hline P1 & $5 ;$ & -CTTCCCTACCCAGAGCCAGGTT -3' \\
P2 & $5 ;$ & -CCCATGCTGGCACGTTCTGAGG - 3' \\
P3 & $5 ;$ & -CCTTCCTCTCACTTGGCCCTGAG -3' \\
P4 & $5 ;$ & -CCCTGGGTGTCCAGGAGCAAGCC -3; \\
\hline
\end{tabular}


Table1: Distribution of alpha thalassaemia mutations in India

\begin{tabular}{|c|c|c|c|}
\hline Mutation & Country & Origin & Reference \\
\hline Deletional $\{\alpha+$ thal. & Central India & Baiga tribe & Reddy et al. (1955) \\
\hline $\begin{array}{l}\text { Mutation in polyadenylation signal of } \\
\text { alpha } 2 \text { gene }\end{array}$ & India & Asian & Hall et al. (1994) \\
\hline Alpha thalassaemia determinant- $60 \%$ & Central India & Indian & Curuk et al. (1993) \\
\hline $\begin{array}{l}\text { An IVS } 1-117(\mathrm{G} \rightarrow \mathrm{A}) \text { acceptor site mutation } \\
\text { in the } \alpha \alpha-2 \text { globin gene. A nondeletioal }\{\alpha- \\
\text { thal } 2 \text { determinant }\end{array}$ & Central India & Tribal population & Curuk et al. (1993) \\
\hline Alpha thalassaemia gene $(-3.7 \&-4.2$ deletion $)$ & Orissa, India & Orissa & Kulozik et al. (1998) \\
\hline $\begin{array}{l}\text { A novel-alpha } 3.5 \text { deletion removing the } \\
\text { alpha } 1 \text { globin gene }\end{array}$ & & & \\
\hline with some of its flanking sequences & Orissa, India & Orissa & Kulozik et al. (1998) \\
\hline Alpha thalassaemia & Assam,India & Kachari population & Hundrieser et al. (1987) \\
\hline Alpha thalassaemia carrier- $90 \%$ & India & Caste and tribal & Mohanty et al. (2002) \\
\hline $\begin{array}{l}\text { Alpha thalassaemia- } 1 \text { deletion with } \\
\text { (novel splice donor mutation) }\end{array}$ & & communities & \\
\hline alpha 2 IVS $1-1(\mathrm{G} \rightarrow \mathrm{A})$ in $\mathrm{Hb} \mathrm{H}$ disease. & India & Indian & Shaji et al. (2003) \\
\hline $\begin{array}{l}\text { Beta thalassaemia association with a new } \\
\text { variant [delta } 116(\mathrm{~g} 18) \text { Arg } \rightarrow \text { Leu] }\end{array}$ & East India & East Indian & Waye et al. (2003) \\
\hline Alpha thalassaeia-1.88\% & Rajasthan, India & Rajasthani & Choubisa et al. (2000) \\
\hline$\{\alpha 3.71 /\{\alpha \mid \alpha$ & Nepal & $\begin{array}{l}\text { Danuwars-6.3\%, } \\
\text { Tamang-5\% }\end{array}$ & Sakai et al. (2004) \\
\hline Alpha thalassaemia & $\begin{array}{l}\text { WB,Assam, } \\
\text { Arunachal } \\
\text { Pradesh, India }\end{array}$ & $\begin{array}{l}\text { Santhal tribe, } \\
\text { Ahom tribe. }\end{array}$ & $\begin{array}{l}\text { Gajra et al. (2003) } \\
\text { Sen et al. (2005) }\end{array}$ \\
\hline
\end{tabular}

\section{RESULTSAND DISCUSSION}

In our present study we have examined a total of 133 DNA samples (Table 2). The cases were mostly non tribal Bengali cases referred to our unit for investigation of Anaemia. The investigations done before selection were that of beta thalassaemia and iron deficiency.

Sixty four cases had common beta mutations. In 36 selected cases of microcytic anaemias we found two common alpha thalassaemia mutations (Table 3). In (Table 4) we studied some selected

Table 2: Total number of DNA samples studied

\begin{tabular}{lr}
\hline Mutation study & Number of cases \\
\hline Common mutations for $\mid \alpha$ thalassaemia & 64 \\
Common $\mid \alpha$ thal. deletions studied & 36 \\
Interaction of both & 33 \\
\hline Total & 133 \\
\hline
\end{tabular}

Table 3: Alpha thalassaemia studies in selected cases of microcytic anaemias

\begin{tabular}{lr}
\hline Genotype & Number of cases \\
\hline$-3.7 \alpha /: \alpha: \alpha$ & 2 \\
$-4.2 \alpha / ; \alpha ; \alpha$ & 2 \\
$-4.2 \alpha /: 4.2 \alpha$ & 1 \\
$-3.7 \alpha /:-4.2 \alpha \mathrm{HbH}$ & 1 \\
$\alpha ; \alpha \alpha: \alpha$ & 30 \\
\hline Total number of analysed cases & 36 \\
\hline
\end{tabular}

referral samples to detect the interaction between two common alpha thalassaemia mutations with existing beta mutations and other haemoglobinopathies in the populations.

\section{CONCLUSION}

In the population studied there are several alpha mutations present either in heterozygous or homozygous states together with the beta mutations and other haemoglobinopathies in several complex cases. At the same time alpha thalassaemia is an asymptomatic disorder and $\mathrm{Hb}$ Electrophoresis can not detect the state as well. Moreover, alpha thalassaemia is misinterpreted with the common iron deficiency anaemia in several suspected cases, so patients coming for $\mathrm{Hb}$ Electrophoresis and carrier detection should be also checked the alpha status through specific DNA studies.

\section{ACKNOWLEDGEMENT}

The authors are thankful to the Secretary, Ramakrishna Mission Seva Pratishthan for allowing the hospital cases to be used and to University Grants Commission, New Delhi and National Tea Research Foundation, India for financial assistance. 
Table 4: Study of the interaction of alpha and beta thalassaemia in selected referral samples

\begin{tabular}{|c|c|c|c|}
\hline $\begin{array}{l}\text { Hb electrophoresis } \\
\text { Report }\end{array}$ & $\begin{array}{l}\text { Genotype for beta } \\
\text { thalassaemia }\end{array}$ & $\begin{array}{c}\text { Genotype for common alpha } \\
\text { thalassaemia deletions }\end{array}$ & Number of cases \\
\hline$\alpha$ thalassaemia & IVS1-5M/ IVS1-5M & $-3.7_{i}^{\prime} \alpha / \alpha_{i}^{\prime} \alpha_{i}^{\prime} \alpha$ & 1 \\
\hline$\alpha$ carrier & Unknown $\alpha$ mut/N & $-3.7 \gamma_{1}^{\prime} \alpha / \alpha_{1}^{\prime} \alpha \alpha$ & 1 \\
\hline$\alpha$ carrier & IVS1-5M/N & $-4.2|\alpha /-4.2| \alpha$ & 1 \\
\hline$\alpha$ carrier & IVS1-5M/N & $-3.7|\alpha /-3.7| \alpha$ & 1 \\
\hline$\alpha c$ arrier & IVS1-5M/N & $-3.7|\alpha / 3.7| \alpha$ & 1 \\
\hline$\alpha c$ carrier & IVS $1-5 \mathrm{M} / \mathrm{N}$ & $-3.7|\alpha / 3.7| \alpha$ & 1 \\
\hline$\alpha c a r r i e r$ & IVS $1-5 \mathrm{M} / \mathrm{N}$ & $-4.2\left|\alpha / \alpha_{1}^{\prime} \alpha\right| \alpha$ & 1 \\
\hline Ecarrier & Codon26/N & $|\alpha|_{i}^{\prime} \alpha / \alpha_{i}^{\prime} \alpha$ & 3 \\
\hline HomozygousE (EE) & Codon26/ Codon26 & $\alpha \alpha_{1}^{\prime} \alpha / \alpha_{1}^{\prime} \alpha$ & 1 \\
\hline$\alpha$ carrier & FS41-42/N & $\alpha_{1}^{\prime} \alpha / \alpha_{1}^{\prime} \alpha$ & 1 \\
\hline$\alpha$ carrier & Codon $15 / \mathrm{N}$ & $\mid \alpha \alpha_{i}^{\prime} \alpha / \alpha_{i}^{\prime} \alpha$ & 1 \\
\hline$\alpha$ thalassaemia & IVS1-5M/ IVS1-5M & $\mid \alpha_{1}^{\prime} \alpha / \alpha_{1}^{\prime} \alpha$ & 1 \\
\hline$\alpha$ carrier & Unknown/N & $\mid \alpha_{1}^{\prime} \alpha / \alpha_{1}^{\prime} \alpha$ & 2 \\
\hline$\alpha$ carrier & IVS1-5M/N & $\left.\alpha\right|_{1} ^{\prime} \alpha / \alpha_{1}^{\prime} \alpha \alpha^{\prime} \alpha$ & 17 \\
\hline Total & & & 33 \\
\hline
\end{tabular}

\section{REFERENCES}

Adhikari D, Lahiri P, Chandra S and Bhattacharya D K 1987. A method for estimating haemoglobin A2 and $\mathrm{E}$ for mass detection of carriers of Thalassaemia. Curr Sci, 56(24): 1281-I283.

Baysal E, Huisman THJ 1994. Detection of common alpha Thalassaemia by PCR. Am J Hematol, 46: 208-213.

Betke K, Marti Hr, Schlicht I 1959. Estimation of small percentages of fetal haemoglobm. Nature, 184: $1877-1878$.

Choubasia SL, Choubasia DK, Khare S 2000. Alpha thalassaemia ( $\mathrm{Hb} \mathrm{Bart}^{-}{ }^{-\mathrm{s}}$ ) in Rajasthan (India) Haematologica (Budap), 30: 209-213.

Curuk MA, Baysal E, Gupta RB, Sharma S, Huisman TH 1993. An IVS 1-117 (G;úA) acceptor splice site mutation in the alpha-1 globin gene is a nondeletional alpha thal-2 determinant in an Indian population $\mathrm{Br}$ J Haematol, 85: 148-152.

Hall GW, Higgs GW, Murrphy P, Villegas A, De Miguel A 1994. A mutation in the polyadenylation signal of the 'Á-2 globin gene (AAATAAA iúAATA-) as a cause of $\mid A$ - thalassaemia in Asian Indians. $B r J$ Haematol, 88: 225-227.

Huindrieser J, Deka R, Gogoi BC 1987. Alpha thalassaemia in the Kachari population of Assam India, Hemoglobin, 11: 517-519.

Kattamis C, Efremov G, Pootrakul S 1981. Effectiveness of one tube osmotic fragility screening in detecting b thalassaemia trait. J Med Genet, 18(4): 266-270.

Kolozik AE, Kar BC, Serjeant GR, Serjeant BE, Weatheall DJ 1988. The molecular basis of 'A-thalassaemia in India. Its interaction with the sickle cell gene. Blood, 71: $467-472$.
Mahadik C, Kapadia C, Yagnik H, Sukumaran P K, Merchant S 1986. One tube osmotic fragility as an useful screening test for thalassaemia carrier. " $\mathrm{C}$ a field experience. Ind J Hematol. 4: 62-64.

Mehta B C, Gandhi S, Mehta J B, Kamath P 1988. Naked eye single tube red cell osmotic fragility test for beta Thalassaemia : population survey. Ind $J$ Hematol, 6: 187-90.

Mohanty D, Colah RB, Gorakshakar AC, Nadkarni AH, Phanasgaonka RP, Shetty S, Ghosh K, Mukherjee MB 2002. Genetic disorders in haematological practice in India. Community Genet, 5: 197-200.

Newton CR, Graham A, Heptinstall L E, Powell S J, Sunmmers C, Kalsheker N, Smith J C and Markham A F 1989. Analysis of any point mutation in DNA. The amplification Refractory Mutation System (ARMS ). Nucleic Acids Research, 17 (7):

Shaji R.V., Srivastava A., Chandy M., Krishnamoorthy R 2000. Single tube multiplex PCR method to detect the common thalassaemia alleles. Blood, 95(5): 1879-1880.

Shaji R.V., Eunce SE, Baidya S, Srivastava A, Chandy M 2003. Determination of the breakpoint and molecular diagnosis of a common alpha thalassaemia -1 deletion in Indian population. Br J Haematol, 123: 942-947.

Waye JS, Patterson M, Walker L, Eng B, Nakamura LM, Lafferty JD, Yong SL, Wu JK, Chui DH, Yong SL 2003. Beta thalassaemia in association with a new delta chain hemoglobin variant [delta 116 (g18) Arg;úLeu] : implications for carrier screening and prenatal diagnosis. Am J Hematol, 74: 179-181.

Worwood M 1994. In: Practical Paematology. JV Dacei, SM Lewis (Eds.). $8^{\text {th }}$ Edition, Churchill Livingstone. Pp. 437-444. 